(c) The Authors 2019. This is an Open Access article, distributed under the terms of the Creative Commons Attribution licence (http:// creativecommons.org/licenses/by/4.0/), which permits unrestricted re-use, distribution, and reproduction in any medium, provided the original work is properly cited.

\title{
A systematic review of the effects of increasing arachidonic acid intake on PUFA status, metabolism and health-related outcomes in humans
}

\author{
Philip C. Calder ${ }^{1,2 *}$, Cristina Campoy ${ }^{3}$, Ans Eilander $^{4}$, Mathilde Fleith ${ }^{5}$, Stewart Forsyth ${ }^{6}$, \\ Per-Olof Larsson ${ }^{7}$, Bettina Schelkle ${ }^{8}$, Szimonetta Lohner ${ }^{9,10}$, Aliz Szommer ${ }^{10}$, \\ Bert J. M. van de Heijning ${ }^{11}$ and Ronald P. Mensink ${ }^{12}$ \\ ${ }^{1}$ Faculty of Medicine, University of Southampton, Southampton SO16 6YD, UK \\ ${ }^{2}$ NIHR Southampton Biomedical Research Centre, University Hospital Southampton NHS Foundation Trust \\ and University of Southampton, Southampton SO16 6YD, UK \\ ${ }^{3}$ Department of Paediatrics, EURISTIKOS Excellence Centre for Paediatric Research, University of Granada, \\ 18016 Granada, Spain \\ ${ }^{4}$ Unilever RED Vlaardingen, 3133 AT Vlaardingen, The Netherlands \\ ${ }^{5}$ Nestlé Research, 1000 Lausanne 26, Switzerland \\ ${ }^{6}$ DSM, 4303 Kaiseraugst, Switzerland \\ ${ }^{7}$ BASF AS, 0283 Oslo, Norway \\ ${ }^{8}$ ILSI Europe, B-1200 Brussels, Belgium \\ ${ }^{9}$ Department of Paediatrics, Clinical Center of the University of Pécs, Medical School, University of Pécs, 7623 Pécs, Hungary \\ ${ }^{10}$ Cochrane Hungary, Clinical Center of the University of Pécs, Medical School, University of Pécs, 7622 Pécs, Hungary \\ ${ }^{11}$ Danone Nutricia Research, 3584 CT Utrecht, The Netherlands \\ ${ }^{12}$ Department of Nutrition and Movement Sciences, NUTRIM School of Nutrition and Translational Research in Metabolism, \\ Maastricht University Medical Center, 6200 MD Maastricht, The Netherlands \\ (Submitted 10 December 2018 - Final revision received 6 March 2019 - Accepted 12 March 2019 - First published online 27 May 2019)
}

\section{Abstract}

We conducted a systematic review of randomised controlled trials (RCT) of increased intake of arachidonic acid (ARA) on fatty acid status and health outcomes in humans. We identified twenty-two articles from fourteen RCT. Most studies were conducted in adults. These used between 80 and $2000 \mathrm{mg}$ ARA per d and were of 1-12 weeks duration. Supplementation with ARA doses as low as $80 \mathrm{mg} / \mathrm{d}$ increased the content of ARA in different blood fractions. Overall there seem to be few marked benefits for adults of increasing ARA intake from the typical usual intake of $100-200 \mathrm{mg} / \mathrm{d}$ to as much as $1000 \mathrm{mg} / \mathrm{d}$; the few studies using higher doses (1500 or $2000 \mathrm{mg} / \mathrm{d}$ ) also report little benefit. However, there may be an impact of ARA on cognitive and muscle function which could be particularly relevant in the ageing population. The studies reviewed here suggest no adverse effects in adults of increased ARA intake up to at least 1000-1500 mg/d on blood lipids, platelet aggregation and blood clotting, immune function, inflammation or urinary excretion of ARA metabolites. However, in many areas there are insufficient studies to make firm conclusions, and higher intakes of ARA are deserving of further study. Based on the RCT reviewed, there are not enough data to make any recommendations for specific health effects of ARA intake.

Key words: Arachidonic acid: $n-6$ Fatty acids: Fatty acids: Human health: Inflammation

Arachidonic acid (ARA) is the common name for all-cis5,8,11,14-eicosatetraenoic acid (Fig. 1), commonly abbreviated to $20: 4 \omega-6$ or $20: 4 n-6$. ARA is a long-chain PUFA (LC-PUFA) within the $n-6$ family. ARA is commonly found in cell membranes, particularly in animals. Therefore meat, especially red meat, and also white meat and fish; offal (organ meat) like liver, kidney and brain; and eggs are sources of ARA. A recent study reported estimated dietary intakes for ARA among adults in 47 developed and 128 developing countries $^{(1)}$; the study reported that $48 \%$ of the 175 countries have an ARA intake

Abbreviations: ARA, arachidonic acid; CE, cholesteryl ester; DGLA, dihomo- $\gamma$-linolenic acid; FA, fatty acid; LA, linoleic acid; LC-PUFA, long-chain PUFA; PL, phospholipid; RCT, randomised controlled trial.

* Corresponding author: Philip C. Calder, email pcc@soton.ac.uk 


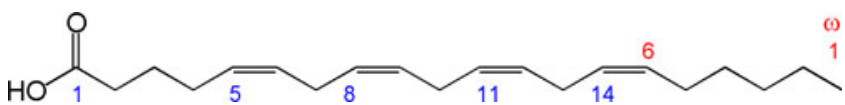

Fig. 1. Structure of arachidonic acid. The numbers 1, 5, 8, 11 and 14 beneath the hydrocarbon chain refer to carbon number counting from the $\alpha$ end of the chain. The numbers 1 and 6 above the hydrocarbon chain refer to carbon number counting from the $\omega$ end of the chain.

of $<150 \mathrm{mg} / \mathrm{d}$. Amongst the developed countries, mean daily ARA intakes were estimated to be between 100 and $350 \mathrm{mg}$ and ARA contributed $<0 \cdot 1 \%$ of total daily energy intake. Data on ARA intake in specific population subgroups are extremely limited ${ }^{(2)}$. Human milk also contains ARA. Brenna et al. ${ }^{(3)}$ reported human milk ARA (as percentage of total fatty acids (FA)) from 106 studies in the range of $0 \cdot 24-1 \%$ with a median of 0.47 (SD 0.13$) \%$. Many infant formulas are supplemented with ARA at a level of $0 \cdot 35-0 \cdot 7 \%$ of total FA.

ARA can be synthesised from the essential $n$ - 6 PUFA linoleic acid (18: $2 n-6$, LA) by a series of desaturation and elongation reactions as shown in Fig. 2. Based upon a study with ${ }^{2} \mathrm{H}$-labelled LA, Emken et $a l .{ }^{(4)}$ reported that $1-2 \cdot 2 \%$ of LA is converted to other $n-6$ PUFA in healthy young adult males with about $0.5 \%$ appearing as ARA.

Despite its relatively low intake from the diet, ARA makes an important contribution to FA within circulating lipids and in most cells and tissues, particularly to membrane phospholipids (PL). For example, ARA has been reported to contribute an average of $9 \cdot 6,6 \cdot 6,15 \cdot 5,9 \cdot 5$ and $16 \%$ of total FA in plasma phosphatidylcholine, plasma cholesteryl esters (CE), erythrocytes, platelets and blood mononuclear cells in healthy British adults who were non-oily-fish consumers and were consuming typical diets $^{(5)}$. The relatively high content of ARA in these pools, in comparison with its intake from the diet, suggests that synthesis from

Linoleic acid (18: 2n-6)

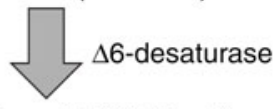

$\gamma$-Linolenic acid (18: 3n-6)

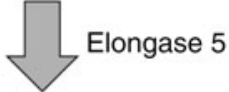

Dihomo- $\gamma$-linolenic acid (20: $3 n-6)$

$\Delta 5$-desaturase

Arachidonic acid (20: 4n-6)

Elongase 2 or 5

Adenic acid (22: 4n-6)

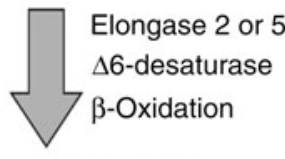

Osbond acid (22: $5 n-6)$

Fig. 2. Outline of the pathway of biosynthesis and further metabolism of arachidonic acid.
LA is an important pathway and that metabolic mechanisms might serve to concentrate and retain ARA in cell membranes. ARA has a structural role in the brain ${ }^{(6,7)}$, free ARA has roles in cell signalling, and ARA-containing PL also have roles in cell signalling and are precursors to endocannabinoids that have a range of biological properties ${ }^{(8)}$. A major role of cell membrane ARA is as a substrate for the synthesis of eicosanoids, which include prostaglandins, thromboxanes and leukotrienes. These are formed by metabolism of ARA by cyclo-oxygenase, lipoxygenase and cytochrome $\mathrm{P} 450$ pathways ${ }^{(9-11)}$. The resulting metabolites have many roles in inflammation and pain, regulation of the immune response, bone turnover, platelet aggregation and blood clotting, smooth muscle contraction and renal function ${ }^{(9-11)}$. These well-known functions of ARA-derived metabolites suggest that ARA itself might impact a range of outcomes related to human health. This has been explored in a small number of human studies, frequently using supplements containing ARA. The first such study was by Seyberth et al. ${ }^{(12)}$. This was a small study involving four healthy men given $6 \mathrm{~g}$ of ethyl arachidonate daily for a period of 2-3 weeks. The authors identified an increased content of ARA in plasma TAG, PL and CE and in platelets, and a mean $47 \%$ increase in excretion of the major urinary metabolite of ARA. The threshold of ADP required to induce platelet aggregation was decreased in all four subjects (by 40-90\%), which was interpreted as an enhanced potential for blood clotting. This was considered to be a major health concern and most likely explains why there was no further interest in studies with ARA supplements in humans until the mid-1990s ${ }^{(13-17)}$.

The aim of this systematic review is to assess the effects of increasing ARA intake through foods or supplements on ARA levels in different compartments, metabolism and health-related outcomes in humans. All health-related outcomes that have been addressed in randomised controlled trials (RCT) investigating increased ARA intake through foods or supplementation were considered. Research gaps were identified and we assessed whether recommendations for ARA intake can be made for specific health effects.

\section{Methods}

Details of the methods used for the systematic review are published in the PROSPERO international prospective register of systematic reviews (registration number: CRD42017076493).

\section{Criteria for considering studies in this review}

Types of study. RCT in humans were included if they measured any human health-related outcome. Observational and nonrandomised interventional studies were excluded.

Types of intervention. Studies were included if they increased intake of ARA through a food or supplement and had a control group with either a lower ARA intake or no ARA supplementation. We excluded studies assessing the effect of the combination of DHA and ARA or the combination of any other FA with ARA. 
Table 1. Search terms used for the Cochrane Central Database search

\begin{tabular}{ll}
\hline 1 & exp Arachidonic Acid/ (18143) \\
2 & arachidonic acid ${ }^{*} . \mathrm{mp} .(46543)$ \\
3 & arachidonate*.mp. (11283) \\
4 & eicosatetraenoic acid.mp. (3825) \\
5 & eicosatetranoic acid ${ }^{*} . \mathrm{mp} .(22)$ \\
6 & $20: 4 n$-6.mp. (932) \\
7 & $20: 4 n-6 . \mathrm{mp} .(986)$ \\
8 & $20: 4 n 6 . \mathrm{mp} .(101)$ \\
9 & or/1-8 (53238) \\
10 & randomi?ed controlled trial.pt. (469845) \\
11 & controlled clinical trial.pt. (94452) \\
12 & randomi?ed.ab. (411841) \\
13 & placebo.ab. (191566) \\
14 & clinical trials as topic.sh. (187518) \\
15 & randomly.ab. (285414) \\
16 & trial.ti. (184903) \\
17 & or/10-16 (1153410) \\
18 & exp animals/ not humans.sh. (4442323) \\
19 & 17 not 18 (1063843) \\
20 & 9 and $19(1502)$ \\
\hline
\end{tabular}

Types of population. Studies of human subjects (infants, children and adults) conducted in any country were included, without restriction on age or health status. We excluded animal and in vitro studies.

Minimum duration of intervention. Duration of ARA intervention and follow-up varied depending on the study design and health outcome measured; we did not place a restriction on this.

Types of outcome measure. All types of health outcomes, including risk markers of disease, were included.
Date of publication: There was no restriction on study inclusion according to the year of publication.

\section{Search methods for identification of studies}

The Cochrane Central Register of Controlled Trials database was searched on 23 August 2017 and again on 23 March 2018 in an update search, using text words with appropriate truncation and relevant indexing terms (Table 1). The keywords for the search were different synonyms related to the intervention (i.e. ARA). The systematic review software Covidence (www.covidence. org) was used to facilitate screening of the literature. Titles and/or abstracts of studies retrieved using the search strategy were screened independently by two review authors (a combination of S. L., A. S., R. P. M., M. F. and B. S.) to identify studies that met the inclusion criteria. The full texts of the potentially eligible studies were retrieved and independently assessed for eligibility by two review team members (a combination of S. L., A. S., R. P. M. and B. S.) with final agreement by all authors. Any disagreement between them over the eligibility of particular studies was resolved through discussion between the two relevant reviewers or the whole group. A standardised, pre-piloted form was used to extract data from the included studies for assessment of study quality and evidence synthesis. Extracted information included study setting; study population and participant demographics and baseline characteristics; details of the intervention and control conditions; study methodology; recruitment and study completion rates; outcomes and times of measurement; and funding. One of the authors (B. v. d. H., R. P. M., M. F. or B. S.) extracted data and the data were
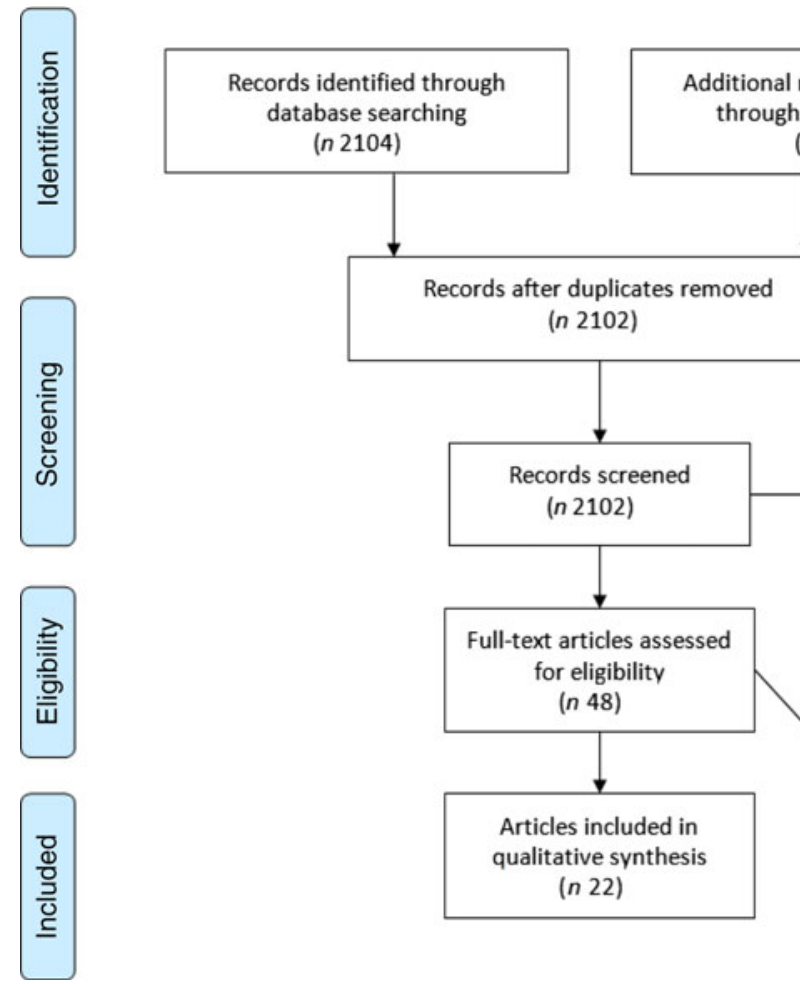

ditional records identified rough other sources (n 69)

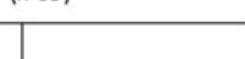

Fig. 3. Preferred Reporting Items for Systematic Reviews and Meta-Analyses (PRISMA) flow chart of study selection. 


\section{N British Journal of Nutrition}

Table 2. Characteristics of the included articles

\begin{tabular}{|c|c|c|c|c|c|c|c|}
\hline \multirow[b]{2}{*}{ Reference } & \multirow[b]{2}{*}{ Country } & \multirow[b]{2}{*}{ Study design } & \multicolumn{2}{|c|}{ Interventions } & \multirow[b]{2}{*}{ Participants } & \multirow[b]{2}{*}{ Outcome } & \multirow[b]{2}{*}{ Funding } \\
\hline & & & $\begin{array}{l}\text { ARA (mg/d in } \\
\text { addition to } \\
\text { diet) }\end{array}$ & Comparator & & & \\
\hline $\begin{array}{l}\text { Barakat } \\
\quad \text { et al. }{ }^{(19)}\end{array}$ & Egypt & $\begin{array}{l}\text { Randomised, controlled, } \\
\text { parallel design with } \\
\text { three interventions } \\
\text { (ARA } v \text {. ARA }+ \\
\text { Praziquantel } v \text {. } \\
\text { Praziquantel) } \\
\text { Experimental period: } \\
\text { Praziquantel was } \\
\text { given once, ARA for } \\
21 \mathrm{~d}(5 \mathrm{~d} / \text { week); } \\
\text { Follow-up at days } 42 \\
\text { and } 62\end{array}$ & $\begin{array}{l}10 \mathrm{mg} / \mathrm{kg} \\
(5 \mathrm{~d} / \text { week })\end{array}$ & $\begin{array}{l}\text { Maize-soyabean } \\
\text { oil blend }\end{array}$ & $\begin{array}{l}\text { Schoolchildren with light, } \\
\text { moderate or heavy } S \text {. } \\
\text { mansoni infection } \\
\text { Age: } 4-6 \text { years } \\
\text { Initial } n 268 \text { (blood } \\
\text { sample not clear); final } \\
\text { at follow-up day } 42, n \\
243 ; \text { final at follow-up } \\
\text { day } 62, n 183 \\
\text { Losses: reasons not } \\
\text { clear }\end{array}$ & $\begin{array}{l}\text { Fatty acid composition } \\
\text { Blood lipids } \\
\text { Platelet aggregation, } \\
\text { bleeding and } \\
\text { haematological } \\
\text { markers } \\
\text { Immune and } \\
\text { inflammatory markers }\end{array}$ & DSM North America \\
\hline $\begin{array}{l}\text { De Souza } \\
\text { et al. }{ }^{(20)}\end{array}$ & USA & $\begin{array}{l}\text { Randomised controlled, } \\
\text { parallel design with } \\
\text { two interventions } \\
\text { (ARA } v \text {. comparator) } \\
\text { Experimental period: } \\
8 \text { weeks during a } \\
\text { training programme }\end{array}$ & 600 & Maize oil & $\begin{array}{l}\text { Healthy men } \\
\text { Age: } 20 \pm 2 \text { years } \\
\text { Initial } n 30 \\
\text { Losses: not clear }\end{array}$ & $\begin{array}{l}\text { Body composition, } \\
\text { physical performance } \\
\text { and muscle function }\end{array}$ & Molecular Nutrition \\
\hline $\begin{array}{l}\text { Emken } \\
\text { et al.(21) } \\
\text { (sub-study } \\
\text { of Nelson } \\
\left.\text { et al. }{ }^{(13)}\right)\end{array}$ & USA & $\begin{array}{l}\text { Trial with two } \\
\text { interventions (ARA } v \text {. } \\
\text { comparator) } \\
\text { Experimental period: } \\
50 \mathrm{~d}\end{array}$ & 1500 & $\begin{array}{l}\text { High-oleic } \\
\text { safflower oil } \\
\text { ( } 271 \mathrm{mg} \text { ARA } \\
\text { per d from } \\
\text { background } \\
\text { diet) }\end{array}$ & $\begin{array}{l}\text { Healthy men } \\
\text { Age: } 21-26 \text { years } \\
n 4\end{array}$ & PUFA metabolism & $\begin{array}{l}\text { Used ARASCO from } \\
\text { Martek Biosciences }\end{array}$ \\
\hline Hirota et al.(22) & Japan & $\begin{array}{l}\text { Random order, cross- } \\
\text { over, controlled design } \\
\text { with two interventions } \\
\text { (ARA v. comparator) } \\
\text { Experimental period: four } \\
\text { successive periods of } \\
3 \text { weeks ( } 3 \text { weeks } \\
\text { washout, } 3 \text { weeks with } \\
\text { treatment } 1,3 \text { weeks } \\
\text { washout and } 3 \text { weeks } \\
\text { with treatment } 2 \text { ) }\end{array}$ & 80 & Olive oil & $\begin{array}{l}\text { Healthy women } \\
\text { Age: } 18-23 \text { years (mean } \\
\text { approximately } 19 \\
\text { years) } \\
\text { Initial } n 23 \\
\text { Losses: not clear, } \\
\text { possibly none }\end{array}$ & Fatty acid composition & Not mentioned \\
\hline $\begin{array}{l}\text { Ishikura } \\
\text { et al. }{ }^{(23)}\end{array}$ & Japan & $\begin{array}{l}\text { Random order, cross- } \\
\text { over, controlled design } \\
\text { with two interventions } \\
\text { (ARA } v \text {. comparator) } \\
\text { Experimental period: } \\
1 \text { month; Washout: } \\
1 \text { month }\end{array}$ & 240 & Olive oil & $\begin{array}{l}\text { Healthy men } \\
\text { Age: } 57-68 \text { years (mean } \\
62 \cdot 8 \pm 2 \cdot 9 \text { years) } \\
\text { Initial } n 25 ; \text { final } n 20 \\
\text { Losses: one reason not } \\
\text { given; four excluded } \\
\text { due to excessive } \\
\text { noise due to } \\
\text { movement during } \\
\text { measurement }\end{array}$ & $\begin{array}{l}\text { Fatty acid composition } \\
\text { Cognition }\end{array}$ & $\begin{array}{l}\text { University of Tokyo } \\
\text { Kyorin University School of } \\
\text { Medicine } \\
\text { Suntory }\end{array}$ \\
\hline
\end{tabular}




\section{Nesitish Journal of Nutrition}

Table 2. (Continued)

\begin{tabular}{|c|c|c|c|c|c|c|c|}
\hline \multirow[b]{2}{*}{ Reference } & \multirow[b]{2}{*}{ Country } & \multirow[b]{2}{*}{ Study design } & \multicolumn{2}{|c|}{ Interventions } & \multirow[b]{2}{*}{ Participants } & \multirow[b]{2}{*}{ Outcome } & \multirow[b]{2}{*}{ Funding } \\
\hline & & & $\begin{array}{l}\text { ARA (mg/d in } \\
\text { addition to } \\
\text { diet) }\end{array}$ & Comparator & & & \\
\hline $\begin{array}{l}\text { Kakutani } \\
\quad \text { et al. }\end{array}$ & Japan & $\begin{array}{l}\text { Randomised, controlled, } \\
\text { parallel design with } \\
\text { three interventions } \\
\text { (two intakes of ARA } \\
\text { V. comparator) } \\
\text { Experimental period: } \\
4 \text { weeks, then } 4 \\
\text { weeks washout }\end{array}$ & $240 ; 720$ & Olive oil & $\begin{array}{l}\text { Healthy elderly ( } n 27 \\
\text { men; } n 37 \text { women) } \\
\text { Age: } 55-70 \text { years (mean } \\
62 \text { years) } \\
\text { Initial } n 66 \text {; final } n 64 \\
\text { Losses: one } \\
\text { discontinuation for } \\
\text { personal reason; one } \\
\text { excluded for meeting } \\
\text { one exclusion criteria }\end{array}$ & $\begin{array}{l}\text { Fatty acid composition } \\
\text { Immune and } \\
\text { inflammatory markers } \\
\text { Urinary metabolites }\end{array}$ & $\begin{array}{l}\text { Tokyo Medical and Dental } \\
\text { University } \\
\text { Suntory }\end{array}$ \\
\hline $\begin{array}{l}\text { Kusumoto } \\
\text { et al. }{ }^{(25)}\end{array}$ & Japan & $\begin{array}{l}\text { Randomised, controlled, } \\
\text { parallel design with } \\
\text { two interventions } \\
\text { (ARA v. comparator) } \\
\text { Experimental period: } \\
4 \text { weeks }\end{array}$ & 838 & Olive oil & $\begin{array}{l}\text { Healthy men (fish } \\
\quad \text { consumers) } \\
\text { Age: } 26-60 \text { years } \\
\text { Initial } n \text { 28; final } n 24 \\
\text { Losses: one developed } \\
\quad \text { tonsillitis and took anti- } \\
\text { inflammatory drugs; } \\
\text { one developed an } \\
\text { infectious disease and } \\
\text { fever; two used anti- } \\
\text { inflammatory drugs }\end{array}$ & $\begin{array}{l}\text { Fatty acid composition } \\
\text { Blood lipids } \\
\text { Blood pressure } \\
\text { Platelet aggregation, } \\
\text { bleeding and } \\
\text { haematological } \\
\text { markers }\end{array}$ & Suntory \\
\hline $\begin{array}{l}\text { Mitchell } \\
\text { et al.(26); } \\
\text { Markworth } \\
\text { et al. }{ }^{(27)}\end{array}$ & New Zealand & $\begin{array}{l}\text { Randomised, controlled, } \\
\text { parallel design with } \\
\text { two interventions } \\
\text { (ARA v. comparator) } \\
\text { Experimental period: } \\
4 \text { weeks }\end{array}$ & 1500 & $\begin{array}{l}\text { Maize-soyabean } \\
\text { oil blend }\end{array}$ & $\begin{array}{l}\text { Healthy men } \\
\text { participating in a } \\
\text { resistance training } \\
\text { programme } \\
\text { Age: } 18-35 \text { years (mean } \\
\text { approximately } 25 \\
\text { years) } \\
\text { Initial } n 21 \text {; final } n 19 \\
\text { Losses: one due to } \\
\text { injury; one due to use } \\
\text { of anti-inflammatory } \\
\text { drugs }\end{array}$ & $\begin{array}{l}\text { Fatty acid composition } \\
\text { Blood lipids } \\
\text { Haematological markers } \\
\text { Body composition, } \\
\text { physical performance } \\
\text { and muscle function }\end{array}$ & $\begin{array}{l}\text { University of Auckland } \\
\text { and DSM Nutritional } \\
\text { Products }\end{array}$ \\
\hline $\begin{array}{l}\text { Nelson et al. } \\
(13,14) ; \\
\text { Kelley } \\
\text { et al. }{ }^{(15,16)} \text {; } \\
\text { Ferretti } \\
\text { et al. }{ }^{(17)}\end{array}$ & USA & $\begin{array}{l}\text { Randomised, controlled, } \\
\text { cross-over design with } \\
\text { two interventions } \\
\text { (ARA } v \text {. comparator) } \\
\text { Experimental period: } \\
\text { standard diet } 1-15 \mathrm{~d} \text {, } \\
\text { cross-over period } 1 \\
\text { between } 16 \text { and } 65 \mathrm{~d} \text {, } \\
\text { cross-over period } 2 \\
\text { between } 66 \text { and } 115 \\
\text { d, washout on } \\
\text { standard diet } \\
116-130 \mathrm{~d}\end{array}$ & 1500 & $\begin{array}{l}\text { High-oleic } \\
\text { safflower oil } \\
\text { (271 mg ARA } \\
\text { per d from } \\
\text { background } \\
\text { diet) }\end{array}$ & $\begin{array}{l}\text { Healthy men } \\
\text { Age: } 20-38 \text { years } \\
\text { Initial } n 12 \text {; final } n 10 \\
\text { Losses: reasons not } \\
\text { given }\end{array}$ & $\begin{array}{l}\text { Fatty acid composition } \\
\text { Blood lipids } \\
\text { Platelet aggregation, } \\
\text { bleeding and } \\
\text { haematological } \\
\text { markers } \\
\text { Immune and } \\
\text { inflammatory markers } \\
\text { Urinary metabolites }\end{array}$ & $\begin{array}{l}\text { Used ARASCO from } \\
\text { Martek Biosciences }\end{array}$ \\
\hline
\end{tabular}




\section{N British Journal of Nutrition}

\begin{tabular}{|c|c|c|c|c|c|c|c|}
\hline \multirow[b]{2}{*}{ Reference } & \multirow[b]{2}{*}{ Country } & \multirow[b]{2}{*}{ Study design } & \multicolumn{2}{|c|}{ Interventions } & \multirow[b]{2}{*}{ Participants } & \multirow[b]{2}{*}{ Outcome } & \multirow[b]{2}{*}{ Funding } \\
\hline & & & $\begin{array}{l}\text { ARA (mg/d in } \\
\text { addition to } \\
\text { diet) }\end{array}$ & Comparator & & & \\
\hline $\begin{array}{l}\text { Pantaleo } \\
\text { et al. }\end{array}$ & Italy & $\begin{array}{l}\text { Randomised, controlled, } \\
\text { parallel design with } \\
\text { two interventions } \\
\text { (ARA } v \text {. comparator) } \\
\text { Experimental period } \\
56 \mathrm{~d} \text {; follow-up after } \\
28 \mathrm{~d} \text { of washout }\end{array}$ & 2000 & Oleic acid & $\begin{array}{l}\text { Patients with cirrhosis } \\
\text { Age: mean } 64 \text { years } \\
\text { Initial } n 30 \text { (eight men } \\
\text { and seven women per } \\
\text { group); final } n 23 \\
\text { Losses: one consent } \\
\text { withdrawn prior to } \\
\text { starting; three } \\
\text { withdrawn due to } \\
\text { adverse events during } \\
\text { the intervention period; } \\
\text { two withdrawn due to } \\
\text { adverse events during } \\
\text { the washout period; } \\
\text { one consent } \\
\text { withdrawn during the } \\
\text { washout period }\end{array}$ & $\begin{array}{l}\text { Fatty acid composition } \\
\text { Platelet aggregation, } \\
\text { bleeding and } \\
\text { haematological } \\
\text { markers } \\
\text { Urinary metabolites }\end{array}$ & $\begin{array}{l}\text { Italian Ministry of } \\
\text { Education, Universities } \\
\text { and Research } \\
\text { University of Florence } \\
\text { Italian Liver Foundation } \\
\text { Martek Biosciences }\end{array}$ \\
\hline $\begin{array}{l}\text { Roberts } \\
\quad \text { et al. }\end{array}$ & USA & $\begin{array}{l}\text { Randomised, controlled, } \\
\text { parallel design, } \\
\text { clusters matched to } \\
\text { age and body mass } \\
\text { with two interventions } \\
\text { (ARA v. comparator) } \\
\text { Experimental period: } \\
50 \mathrm{~d}\end{array}$ & 1000 & Maize oil & $\begin{array}{l}\text { Healthy men } \\
\text { Age: mean } 22 \pm 5 \text { years } \\
\text { Initial } n 31 \text {; final } n 31\end{array}$ & $\begin{array}{l}\text { Blood lipids } \\
\text { Platelet aggregation, } \\
\text { bleeding and } \\
\text { haematological } \\
\text { markers } \\
\text { Immune and } \\
\text { inflammatory markers } \\
\text { Body composition, } \\
\text { physical performance } \\
\text { and muscle function }\end{array}$ & Molecular Nutrition \\
\hline $\begin{array}{l}\text { Schubert } \\
\text { et al. }\end{array}$ & Germany & $\begin{array}{l}\text { Randomised, parallel } \\
\text { design with two } \\
\text { interventions (ARA } v \text {. } \\
\text { bioactive oil blend) } \\
\text { Experimental period: } \\
2 \text { weeks; follow-up } \\
2 \text { weeks after stopping } \\
\text { the intervention }\end{array}$ & 40 & $\begin{array}{l}\text { Blend of other } \\
\text { bioactive fatty } \\
\text { acids }\end{array}$ & $\begin{array}{l}\text { Healthy adults } \\
\text { Age: } 20-38 \text { years (mean } \\
28 \text { years) } \\
\text { Initial } n 30 \\
\text { Losses: not clear, } \\
\text { possibly none }\end{array}$ & $\begin{array}{l}\text { Fatty acid composition } \\
\text { Immune and } \\
\text { inflammatory markers }\end{array}$ & None mentioned \\
\hline Selim et al.(31) & Egypt & $\begin{array}{l}\text { Randomised, controlled, } \\
\text { parallel design with } \\
\text { three interventions } \\
\text { (ARA } v \text {. ARA }+ \\
\text { Praziquantel } v \text {. } \\
\text { Praziquantel) } \\
\text { Experimental period: } \\
\text { Praziquantal was } \\
\text { given once, ARA for } \\
21 \mathrm{~d}(5 \mathrm{~d} / \text { week); } \\
\text { follow-up at days } \\
28 \text { and } 62\end{array}$ & $\begin{array}{l}10 \mathrm{mg} / \mathrm{kg} \\
(5 \mathrm{~d} / \text { week })\end{array}$ & $\begin{array}{l}\text { Maize-soyabean } \\
\text { oil blend }\end{array}$ & $\begin{array}{l}\text { Schoolchildren } \\
\text { Age: } 6-15 \text { years } \\
\text { Initial } n 66 \\
\text { Losses: none but fatty } \\
\text { acids reported for a } \\
\text { sub-sample }\end{array}$ & $\begin{array}{l}\text { Fatty acid composition } \\
\text { Blood lipids } \\
\text { Platelet aggregation and } \\
\text { haematological } \\
\text { markers } \\
\text { Immune and } \\
\text { inflammatory markers }\end{array}$ & DSM North America \\
\hline
\end{tabular}


double-checked by another member in the team. A flow chart of the literature identification can be found in Fig. 3 .

Reference lists of all the eligible papers and relevant systematic reviews were searched for additional studies.

\section{Risk of bias assessment}

Three authors independently (R. P. M., M. F. and B. S.) assessed the risk of bias in included studies by following the Cochrane Risk of Bias guidelines ${ }^{(18)}$, and any disagreement between them was resolved through discussion.

\section{Results}

\section{CENTRAL search}

A total of 2104 titles and abstracts were identified via the electronic search from which 1255 duplicates were removed. Additional references ( $n$ 69) were found via reference screening of review papers found in the electronic search, of which thirtysix were duplicates. In total, 1964 titles were excluded as irrelevant based on title and abstract considering the inclusion and exclusion criteria. The remaining forty-eight papers were screened based on full text, and twenty-two were considered as relevant for review inclusion. A flow chart of the literature identification process can be found in Fig. 3. The twenty-two articles included in the systematic review ${ }^{(13-17,19-35)}$ came from fourteen individual studies. Table 2 summarises these studies. Most studies were conducted in healthy young or older adults and several were restricted to men. One study was conducted in breast-feeding women, one in patients with liver cirrhosis and two in children with parasitic worm infestation. Studies in adults used between 80 and $2000 \mathrm{mg}$ ARA per d, were of 1-8 weeks duration and usually used ARA as a supplement.

\section{Risk of bias assessment}

The overall risk of bias analysis shows that for many studies bias is unclear due to insufficient reporting of required details essential for an informed decision (Fig. 4).

Fatty acid composition in different compartments. A number of included studies reported the effect of increased intake of ARA on the FA composition of one or more blood pools.

Nelson and colleagues ${ }^{(13-17)}$ performed a placebo-controlled, random order, cross-over study in twelve healthy male participants housed in a metabolic unit. Participants consumed a stabilisation diet that contained about $200 \mathrm{mg} / \mathrm{d}$ ARA for $15 \mathrm{~d}$, and then either continued on the stabilisation diet for $50 \mathrm{~d}$ or consumed a diet that provided $1.7 \mathrm{~g} / \mathrm{d}$ ARA for $50 \mathrm{~d}$. After that, the participants crossed over to the other diet for $50 \mathrm{~d}$, followed by $15 \mathrm{~d}$ of the stabilisation diet. Ten participants completed the study. The FA compositions of plasma, plasma TAG, CE, PL and NEFA, erythrocytes, adipose tissue ${ }^{(14)}$ and platelets ${ }^{(13)}$ were reported. There was a near doubling of plasma ARA when ARA was consumed (approximately from 8 to $16 \%$ of total FA) which was accompanied by a decrease in LA. ARA increased in plasma TAG, CE (approximately from 7.5 to $15 \%$ of FA) and PL (approximately from 10 to $19 \%$ of $\mathrm{FA}$ ) again mainly at the 


\begin{tabular}{|c|c|c|c|c|c|c|c|}
\hline \multirow[b]{2}{*}{ Reference } & Selection bias & Selection bias & Performance bias & Detection bias & Attrition bias & Reporting bias & Other bias \\
\hline & $\begin{array}{c}\text { Random sequence } \\
\text { generation }\end{array}$ & $\begin{array}{l}\text { Allocation } \\
\text { concealment }\end{array}$ & $\begin{array}{c}\text { Blinding of } \\
\text { participants and } \\
\text { personnel }\end{array}$ & $\begin{array}{l}\text { Blinding of } \\
\text { outcome } \\
\text { assessment }\end{array}$ & $\begin{array}{l}\text { Incomplete } \\
\text { outcome data }\end{array}$ & $\begin{array}{l}\text { Selective } \\
\text { outcome } \\
\text { reporting }\end{array}$ & Other bias \\
\hline \multicolumn{8}{|l|}{ Barakat et al. ${ }^{(20)}$} \\
\hline \multicolumn{8}{|l|}{ De Souza et al.(21) } \\
\hline \multicolumn{8}{|l|}{ Emken et al. . $^{(22)}$} \\
\hline \multicolumn{8}{|l|}{ Hirota et al..$^{(23)}$} \\
\hline \multicolumn{8}{|l|}{ Ishikura et al. (24) } \\
\hline \multicolumn{8}{|l|}{ Kakutani et al. (25) } \\
\hline \multicolumn{8}{|l|}{ Kusumoto et al. ${ }^{26)}$} \\
\hline \multicolumn{8}{|c|}{$\begin{array}{l}\text { Mitchell et al. }{ }^{(27) ;} \\
\text { Markworth et al. }{ }^{2(8)}\end{array}$} \\
\hline \multicolumn{8}{|c|}{$\begin{array}{l}\text { Nelson et al. }(13,14) ; \\
\text { Kelley et al. }(15,16) ; \\
\text { Ferretti et al. }{ }^{(17)}\end{array}$} \\
\hline \multicolumn{8}{|l|}{ Pantaleo et al. ${ }^{(29)}$} \\
\hline \multicolumn{8}{|l|}{ Roberts et al. ${ }^{(30)}$} \\
\hline \multicolumn{8}{|l|}{ Schubert et al. ${ }^{(31)}$} \\
\hline \multicolumn{8}{|l|}{ Selim et al. ${ }^{(32)}$} \\
\hline \multicolumn{8}{|l|}{ Smit et al. ${ }^{(33)}$} \\
\hline Thies et al. ${ }^{(34-36)}$ & & & & & & & \\
\hline
\end{tabular}

Fig. 4. Risk of bias analyses. Under 'other bias' power analyses, statistical shortcomings (e.g. only within-treatment comparisons) and experimental design issues were considered. Legend: green: low risk of bias; red: high risk of bias; orange: unclear risk of bias.

expense of LA. There was a small increase in ARA in erythrocytes and platelets but no change in adipose tissue ARA. Increases in ARA content were not reflected in any changes in EPA or DHA, except in erythrocytes where DHA content decreased.

Thies et al. ${ }^{(33-35)}$ performed a placebo-controlled, randomised, parallel study in healthy older British subjects: eight participants received a blend of palm and sunflower seed oils as control, while eight received approximately $700 \mathrm{mg}$ ARA (from ARASCO) daily for 12 weeks. Participant's habitual intake of ARA was about $150 \mathrm{mg} / \mathrm{d}$. Blood samples were collected at baseline and at 4,8 and 12 weeks supplementation and then after 4 weeks washout. The FA compositions of plasma $\mathrm{PL}^{(33)}$ and blood mononuclear cells ${ }^{(34)}$ were reported. In plasma PL, ARA increased from 9.3 to $16 \%$ of FA by 4 weeks and did not increase further, but returned to baseline levels after 4 weeks washout ${ }^{(33)}$. Plasma PL ARA levels were significantly higher in the ARA group than in the control group at weeks 4,8 and 12. The increase in ARA in plasma PL did not significantly affect LA, EPA and DHA levels. In mononuclear cells, ARA increased significantly from approximately $20 \%$ of total FA at baseline to approximately $23 \%$ at 8 and 12 weeks $^{(34)}$. This increase was mainly compensated for by a decrease in LA. EPA and DHA levels in mononuclear cells were not affected by ARA supplementation. ARA levels in mononuclear cells were not significantly different between the ARA and control groups.

Pantaleo et $a l^{(28)}$ evaluated if ARA supplementation could increase ARA levels in plasma and erythrocyte lipids in Italian patients with liver cirrhosis. Patients received either $2 \mathrm{~g}$ ARA (as 4 g ARASCO) daily or oleic acid as control for 8 weeks. ARA supplementation for 8 weeks significantly increased ARA levels in plasma total lipids, plasma PL and erythrocytes. This increase was transitory, since ARA levels returned to baseline
4 weeks after cessation of supplementation. No changes in ARA levels were observed in the control group. There was no significant effect of ARA on LA in plasma total lipids, plasma PL or erythrocytes, although LA was numerically lower in all three pools after ARA compared with before. No results were given for $n-3$ FA levels, and no between-group comparison was made.

Schubert et $a l^{(30)}$ compared the effect of two different fat blends on the FA status of thirty healthy German adults. Participants were randomly distributed into two groups receiving for 2 weeks either an oil blend providing $240 \mathrm{mg} / \mathrm{d}$ of $\alpha$ linolenic acid, $120 \mathrm{mg} / \mathrm{d}$ of EPA, $49 \mathrm{mg} / \mathrm{d}$ of stearidonic acid and $73 \mathrm{mg} / \mathrm{d}$ of $\boldsymbol{\gamma}$-linolenic acid in three capsules per $\mathrm{d}$ or an oil providing $40 \mathrm{mg}$ ARA per $\mathrm{d}$ in one capsule per $\mathrm{d}$ plus two olive oil capsules per d. Results showed that $40 \mathrm{mg} / \mathrm{d}$ ARA supplementation for 2 weeks did not increase plasma or erythrocyte ARA. This lack of change is most likely because of the low amount of ARA provided. Between-group comparison, done at each time point, showed that EPA was higher in plasma lipids after the 2 weeks supplementation period in the group receiving the blend containing EPA than in the ARA group.

Kusumoto et al. ${ }^{(25)}$ carried out a double-blind, placebocontrolled study in healthy Japanese men consuming a high fish diet. One group of men received capsules providing $838 \mathrm{mg}$ ARA incorporated into a TAG derived from Mortierella alpina (SUNTGA40S) daily for 4 weeks, while another group received capsules with olive oil as control. FA in serum PL and TAG were measured in fasted blood at four time points: baseline, after 2 and 4 weeks of supplementation and 4 weeks after the end of supplementation. Supplementation with ARA increased ARA content of serum PL from 9.6 to 13.7 (after 2 weeks) and 13.9\% (after 4 weeks) of total FA, which was significantly different from baseline, and then ARA content decreased to a level close to that 
of baseline 4 weeks after the end of supplementation. Serum PL ARA did not change in the control group. The same pattern was observed in serum TAG, although levels of ARA were lower in this lipid class than in PL. Between-group comparison showed a significantly higher ARA content in serum PL, but not in serum TAG, in the group supplemented with ARA than in the control group, after 2 and 4 weeks supplementation. In serum PL, LA was significantly lower than baseline after 2 and 4 weeks ARA supplementation, while it was unchanged in the control group and in serum TAG. Between-group comparison showed no significant difference in LA in serum PL or TAG. There was no significant change in plasma PL or TAG EPA and DHA. This study shows that in a healthy male adult population with high fish intake (approximately $860 \mathrm{mg}$ EPA+DHA intake per d) and a basal intake of approximately $177 \mathrm{mg}$ ARA per d, supplementation with $838 \mathrm{mg} / \mathrm{d}$ is able to increase ARA levels in serum PL without compromising EPA and DHA levels.

Ishikura et $a l .{ }^{(23)}$ supplemented the habitual diet of Japanese elderly men with three capsules per d providing either $240 \mathrm{mg}$ ARA in the form of ARA-enriched TAG (SUNTGA40S; $600 \mathrm{mg}$ oil) or control (600 mg olive oil per d) for 1 month. ARA supplementation significantly increased ARA content in serum PL (from $140 \mu \mathrm{g} / \mathrm{ml}$ serum to $175 \mu \mathrm{g} / \mathrm{ml}$ serum; this was equivalent to an increase from 8.7 to $10.7 \%$ of FA), and significantly decreased EPA but did not affect DHA. In the control group, there was no change in ARA, EPA or DHA levels. No between-group comparison was made.

Hirota et al. ${ }^{(22)}$ performed a double-blind, random order cross-over, placebo-controlled intervention study with twentythree young Japanese women aged 18-23 years. The subjects received one $200 \mathrm{mg}$ capsule daily, either containing a low dose of ARA (approximately $80 \mathrm{mg}$ per $\mathrm{d}$ in $200 \mathrm{mg}$ ARA enrichedTAG) or olive oil as control. The study duration was 12 weeks in total, including four successive periods of 3 weeks: 3 weeks washout, 3 weeks with treatment 1,3 weeks washout and 3 weeks with treatment 2 . The participants were asked to limit their fish consumption to a maximum of four times per week. They recorded their food intake throughout the study, allowing their FA intake at the beginning and at the end of the two treatment periods to be estimated. Fasted blood was taken at the beginning (baseline value) and at the end of the two 3-week treatment periods, and FA were analysed in erythrocyte and plasma PL, TAG and CE. ARA supplementation significantly increased ARA and total $n-6$ LC-PUFA levels in the four blood pools compared with olive oil, without decreasing $n$-3 LC-PUFA, except for a significant decrease in $n-3$ LC-PUFA in plasma CE. This study shows that in a female population with relatively high fish intake (460-560 mg EPA + DHA intake per d) and a basal intake of approximately $150 \mathrm{mg}$ ARA per $\mathrm{d}$, supplementation with a small dose of ARA (approximately $80 \mathrm{mg} / \mathrm{d}$ ) is able to significantly increase ARA levels in erythrocyte and plasma fractions without compromising $n$-3 LC-PUFA levels.

Kakutani et $a l^{(24)}$ performed a double-blind, parallel, placebo-controlled intervention study in 118 healthy Japanese elderly who were not supplement consumers. They received ten $170 \mathrm{mg}$ capsules daily, either containing a low dose or a high dose of ARA (total of approximately $240 \mathrm{mg}$ or approximately $720 \mathrm{mg} / \mathrm{d}$ ) as an ARA enriched-TAG (SUNTGA40S) or olive oil as control for 4 weeks, followed by a 4 -week washout period. The participants recorded their food intake throughout the study, allowing to calculate their FA intake at the baseline and after 4 weeks of supplementation. FA in plasma PL were measured in fasted blood at four time points: baseline, after 2 and 4 weeks of supplementation and 4 weeks after the end of supplementation. Supplementation with 240 and $720 \mathrm{mg} / \mathrm{d}$ of ARA increased ARA content of plasma PL by $2.5 \%$ and $5.6 \%$ of total FA, respectively, which was significantly different from baseline, and then ARA decreased to a level close to that of baseline 4 weeks after the end of supplementation. Plasma ARA did not increase in the control group. Between-group comparison was done but not clearly reported. The ARA increase in plasma PL was dose dependent, at least up to $720 \mathrm{mg} / \mathrm{d}$. In the high ARA group, plasma PL LA was significantly lower than at baseline after 2 and 4 weeks supplementation, while it was unchanged in the low ARA and the control groups. There was no significant change in plasma PL EPA and DHA. This study shows that in an elderly population with high fish intake (853-1176 mg EPA + DHA intake per d) and a basal intake of approximately $170 \mathrm{mg}$ ARA per d, supplementation with a 240 or $720 \mathrm{mg} / \mathrm{d}$ is able to dose-dependently increase ARA levels in plasma PL without compromising EPA and DHA levels.

Recently Markworth et al. ${ }^{(27)}$ reported from a RCT of $1500 \mathrm{mg}$ ARA per $\mathrm{d}$ for 4 weeks in young men participating in a resistance training programme. FA were measured in plasma and in skeletal muscle at the start and end of the supplementation period. Plasma ARA increased from 8.4 to $16 \cdot 2 \%$ of total FA and was higher in the ARA group than in the control group at the end of the intervention. Plasma LA decreased from 25 to $14 \%$ of total FA in the ARA group. Plasma EPA decreased slightly in the ARA group but was not different between groups at week 4. Plasma DHA was not significantly altered. Skeletal muscle ARA increased from 12 to $14.6 \%$ of total FA but this was not a significant effect.

Smit et $a l .{ }^{(32)}$ performed a randomised, open intervention study in twenty breast-feeding Israeli women. The women's mean age was 23 years and the lactation duration ranged between 3 and 10 months. The ARA group received $284 \mathrm{mg}$ ARA per d ( $0.8 \mathrm{ml}$ ARA-rich oil), while the control group did not receive any supplement. The study duration was 1 week, during which three milk samples were taken (before, after $1 \mathrm{~d}$ and after $7 \mathrm{~d}$ supplementation). Milk FA were analysed and the FA composition of the two groups was compared at the three time-points. It was found that women in the ARA group had the same content of ARA in their milk as women who did not receive any supplement. Other long chain $n-6$ PUFA and DHA did not differ either, while EPA was significantly lower in the ARA group at day 7 . This small study suggests that in a population of lactating women with a habitual estimated ARA intake of approximately $200 \mathrm{mg} / \mathrm{d}$, a supplement of approximately $300 \mathrm{mg}$ ARA per d does not significantly affect milk ARA (or DHA), but does lower milk EPA. This effect can be observed after 1 week of ARA supplementation.

In Egyptian schoolchildren infected with Schistosoma mansoni, ARA ( $10 \mathrm{mg} / \mathrm{kg}$ body weight per $\mathrm{d}$ for $5 \mathrm{~d}$ in each of 3 weeks) significantly increased plasma ARA from 7.9 to $12 \cdot 1 \%$ of total FA, with no significant effect on LA ${ }^{(19)}$. 


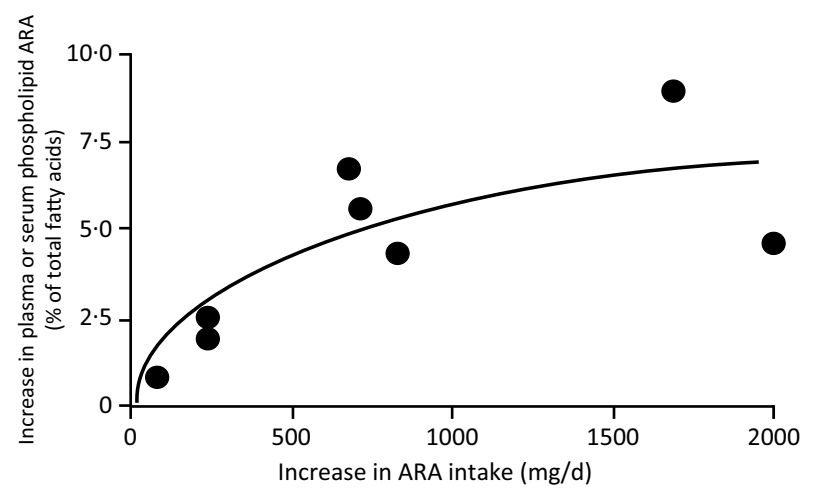

Fig. 5. Relationship between arachidonic acid (ARA) intake $(\mathrm{mg} / \mathrm{d})$ and increment in ARA in serum or plasma phospholipids (as percentage of total fatty acids). Data are taken from Hirota et al. (22), Ishikura et al. ${ }^{(23)}$, Kakutani et al. ${ }^{(24)}$ (two doses of ARA used), Kusumoto et al. (25), Nelson et al. ${ }^{(14)}$, Pantaleo et al..(28) and Thies et al. ${ }^{(33)}$. The line of best fit for these data points is shown.

In summary, increased ARA intake significantly increases the ARA content in different blood fractions, including erythrocytes, platelets and mononuclear cells, with doses as low as $80 \mathrm{mg} / \mathrm{d}$ being effective. The low dose of $40 \mathrm{mg}$ ARA per d did not affect ARA level in plasma or erythrocytes of healthy adults. It is likely that enrichment of ARA in different compartments and pools is dose dependent. Fig. 5 shows data for serum and plasma PL from seven studies and indicates a near linear dose-dependent increase in ARA content up to an intake of about $1000 \mathrm{mg} / \mathrm{d}$. Lack of studies using higher intakes of ARA and the short duration of most studies performed to date limit a full understanding of this dose-response relationship. A study specifically designed to assess the dose-response relationship is required to be certain about the exact nature of this relationship. EPA was decreased in several studies (human milk with $300 \mathrm{mg} / \mathrm{d}$ ARA, plasma CE with $80 \mathrm{mg} / \mathrm{d}$ ARA, serum PL with $240 \mathrm{mg} / \mathrm{d}$ ARA and plasma with $1500 \mathrm{mg} / \mathrm{d}$ ARA) and one study reported a decrease in DHA content of erythrocytes when a high dose $(1.7 \mathrm{~g} / \mathrm{d})$ of ARA was consumed for $50 \mathrm{~d}$.

\section{Effect of arachidonic acid on PUFA metabolism}

A small sub-study ${ }^{(21)}$ within the larger study by Nelson et al. ${ }^{(13,14)}$ investigated the effect of ARA on $\Delta 5$-desaturation and incorporation of ${ }^{2} \mathrm{H}$-labelled dihomo- $\gamma$-linolenic acid (DGLA; $20: 3 n-6$ ) into plasma lipids. Adult male subjects $(n$ 4) were given diets containing either $1.7 \mathrm{~g} / \mathrm{d}$ ARA or $0.21 \mathrm{~g} / \mathrm{d}$ ARA for $50 \mathrm{~d}$. After $50 \mathrm{~d}$, subjects were dosed with a mixture containing ${ }^{2} \mathrm{H}$-labelled ethyl esters of DGLA[d4] and oleic acid[d2], and a series of blood samples were sequentially drawn over a 72-h period. The estimated conversion of DGLA[d4] to ARA[d4] was $17 \cdot 7 \pm 0.8 \%$ when subjects had been on the high ARA intake and $2 \cdot 1 \pm 1 \cdot 4 \%$ when subjects had been on the low ARA intake. The concentrations of ARA[d4] in total plasma lipids from subjects after the high and low ARA periods were $2 \cdot 1 \pm 0.6$ and $0.3 \pm$ $0 \cdot 2 \mu \mathrm{mol} / \mathrm{ml}$ plasma $/ \mathrm{mmol}$ of DGLA[d4] fed per $\mathrm{kg}$ of body weight. These data indicate that conversion of DGLA[d4] to ARA[d4] was stimulated 7- to 8-fold by the high ARA intake, although a decrease in turnover of ARA in the high ARA group cannot be excluded.
Effect of arachidonic acid on blood lipid concentrations

Roberts et al. ${ }^{(29)}$ conducted a study in resistance-trained male subjects and found that serum cholesterol concentrations were not changed after ARA supplementation (1 g/d for $50 \mathrm{~d}$ ). Likewise, there were no changes in serum concentrations of total, LDL- and HDL-cholesterol, TAG, apo AI, apo B or lipoprotein (a) after ARA supplementation in different study designs (see Table 2) in adults ${ }^{(14,25,27)}$ and schoolchildren ${ }^{(19,31)}$.

Thus, from the available evidence it appears that increasing ARA intake even up to $1.7 \mathrm{~g} / \mathrm{d}$ does not affect blood lipid concentrations. However, there are few such studies and the effect of ARA on blood lipids in dyslipidaemic subjects has not been investigated.

\section{Effect of arachidonic acid on blood pressure}

In the study of Kusumoto et al. ${ }^{(25)}$, blood pressure was not affected by increasing ARA intake to $838 \mathrm{mg} / \mathrm{d}$. Participants in this study were normotensive and there are no studies of increasing ARA intake on blood pressure in hypertensive subjects.

\section{Effect of arachidonic acid on platelet aggregation, bleeding and haematological markers}

In a randomised double-blind trial in Italian patients with liver cirrhosis, Pantaleo et al. ${ }^{(28)}$ compared the effects of $2 \mathrm{~g} / \mathrm{d}$ ARA from ARASCO for 8 weeks with those of oleic acid on collagen-induced aggregation of platelet-rich plasma. Compared with pre-study levels, platelet aggregation was significantly increased in the ARA group, but not in the oleic acid group.

Kusumoto et al. ${ }^{(25)}$ carried out a double-blind, placebocontrolled study in healthy Japanese men consuming a high fish diet. One group of men received capsules providing $838 \mathrm{mg}$ ARA incorporated into TAG (SUNTGA40S) daily for 4 weeks, while another group received capsules with olive oil as control. Collagen-, ARA- and ADP-induced aggregation of platelet-rich plasma were not affected by ARA supplementation. Also, haematological parameters ( $\mathrm{Hb}$ concentration, packed cell volume, erythrocyte numbers, total leucocytes, thrombocytes and mean of corpuscular volume) and coagulation parameters (prothrombin time and antithrombin III activity) remained unchanged.

In a single-blind cross-over study, healthy male volunteers received $1.7 \mathrm{~g} / \mathrm{d}$ or $0.2 \mathrm{~g} / \mathrm{d}$ of ARA for $50 \mathrm{~d}^{(13)}$. Aggregation of platelet-rich plasma was induced using ADP, collagen, and ARA. No effects of increased ARA intake were observed. Also, platelet count, bleeding time, partial thromboplastin time and antithrombin III concentrations remained unchanged. Prothrombin time, however, was significantly lowered by about $10 \%$ after ARA intake.

In a randomised double-blind study, resistance-trained male subjects received either ARA ( $1 \mathrm{~g} / \mathrm{d}$ ) or maize oil as placebo for $50 \mathrm{~d}^{(29)}$. There was no effect on erythrocyte numbers.

Most haematological parameters were not altered by $1500 \mathrm{mg} / \mathrm{d}$ ARA for 4 weeks in healthy young men ${ }^{(27)}$.

Haematological parameters ( $\mathrm{Hb}$ concentration, packed cell volume, erythrocyte numbers, numbers of segmented neutrophils, eosinophils, basophils and platelets) were not changed in a study with Egyptian schoolchildren who received ARA 
(10 mg/kg body weight per d) for $15 \mathrm{~d}$ ( $5 \mathrm{~d}$ over each of 3 consecutive weeks) with or without praziquantel, a medication used to treat certain types of parasitic worm infection ${ }^{(19)}$. Several coagulation parameters (prothrombin concentration, international normalised ratio and partial thromboplastin time) were also not changed, although both prothrombin time and clotting time were significantly shorter, although only by $<2 \%{ }^{(19)}$. Comparable results were found in a smaller study in older schoolchildren using a similar design ${ }^{(31)}$.

In summary, most studies report no effect of increased ARA intake on platelet aggregation or coagulation parameters, and no studies report effects on bleeding time. However, the study that used the highest intake of ARA $^{(28)}$ reported enhanced platelet aggregation. The early study of Seyberth et al. ${ }^{(12)}$ using $6 \mathrm{~g}$ ARA per $\mathrm{d}$ also saw this effect. The effect of doses of ARA of $2 \mathrm{~g} / \mathrm{d}$ or more on platelet aggregation requires further investigation.

\section{Effect of arachidonic acid on biomarkers of immunity and} inflammation

Kelley et al. ${ }^{(15,16)}$ reported data from a controlled, cross-over trial in ten healthy adult men in the USA; this is the same study as Nelson et al. ${ }^{(13,14)}$. The participants consumed a standard diet providing $0.21 \mathrm{~g}$ ARA per $\mathrm{d}$ or an intervention diet providing $1.7 \mathrm{~g}$ ARA per $\mathrm{d}$ for $50 \mathrm{~d}$. ARA did not influence ex vivo lymphocyte proliferation in response to several agents or ex vivo natural killer cell activity ${ }^{(15)}$. Participants received the measles/mumps/ rubella and influenza vaccines: the ex vivo proliferation of lymphocytes in response to influenza vaccine was about 4-fold higher in the group receiving $1.7 \mathrm{~g}$ ARA per $\mathrm{d}$ than in the low ARA group ${ }^{(15)}$. However, serum antibody titres against the influenza vaccine were not affected by high $\mathrm{ARA}^{(16)}$. Although the total number of leucocytes was not affected, there were significantly more blood granulocytes (mainly neutrophils) when participants received $1.7 \mathrm{~g}$ ARA per $\mathrm{d}^{(15)}$. However, blood lymphocyte and monocyte numbers were not affected by ARA $^{(16)}$. Ex vivo production of several inflammatory cytokines in response to lipopolysaccharide was not different between low and high ARA treatment ${ }^{(16)}$. However, lipopolysaccharidestimulated production of $\mathrm{PGE}_{2}$ and leukotriene $\mathrm{B}_{4}$ was significantly higher after high ARA than after the standard diet ${ }^{(16)}$. This probably reflects the higher ARA content of the cells involved, although this was not reported.

Thies et al . $^{(33-35)}$ reported results from a placebo-controlled, randomised, parallel study in healthy older British subjects: eight participants received a blend of palm and sunflower seed oils as control, while eight received approximately $700 \mathrm{mg}$ ARA (from ARASCO) daily for 12 weeks. Participant's habitual intake of ARA was about $150 \mathrm{mg} / \mathrm{d}$. Blood samples were collected at baseline and at 4, 8 and 12 weeks supplementation and then after 4 weeks washout. There was no effect of increased intake of ARA on the numbers or percentages of different types of immune cells in the blood, on ex vivo blood lymphocyte proliferation in response to mitogenic stimulation, on ex vivo production of T-cell derived cytokines or lipopolysaccharide-stimulated cytokines, on ex vivo natural killer cell activity, on phagocytic activity and respiratory burst of neutrophils and monocytes or on the plasma concentrations of three different adhesion molecules ${ }^{(33-35)}$. This study clearly demonstrates that there is no strong impact of approximately $700 \mathrm{mg} / \mathrm{d}$ ARA on blood immune cell numbers, on ex vivo markers of the immune response or on markers of inflammation in healthy older subjects. The study did not measure concentrations or production of ARA-derived lipid mediators like prostaglandins.

Roberts et al. ${ }^{(29)}$ saw no effect of $1 \mathrm{~g}$ ARA per $\mathrm{d}$ for $50 \mathrm{~d}$ on total blood leucocyte numbers or types in resistance trained men.

Schubert et al ${ }^{(30)}$ performed a study comparing a mix of FA considered to be anti-inflammatory with ARA ( $40 \mathrm{mg} / \mathrm{d})$ for 2 weeks in thirty healthy participants; an additional blood sample was collected 2 weeks after stopping the intervention. Whole blood was stimulated ex vivo with lipopolysaccharide and appearance of $\mathrm{PGE}_{1}$ (produced from DGLA), $\mathrm{PGE}_{2}$, leukotriene $\mathrm{B}_{4}$, TNF, IL-8 and IL-10 were measured. There were no significant differences in any of these at the end of supplementation compared with baseline in either group, and there were no significant differences between the two groups at the end of the supplementation period. However, some differences were seen between groups 2 weeks after stopping the supplementation; these are difficult to interpret.

Kakutani et al. ${ }^{(24)}$ performed a double-blinded, parallel, placebo-controlled intervention study with 118 healthy Japanese elderly subjects. They received olive oil as control or capsules providing approximately $240 \mathrm{mg}$ or approximately 720 mg ARA per d for 4 weeks, followed by a 4-week washout period. There was no impact of ARA on circulating concentrations of C-reactive protein, IgE, two pro-inflammatory cytokines (TNF and IL-6), $\mathrm{PGE}_{2}$ or lipoxin $\mathrm{A}_{4}$. The authors concluded that there was no impact of 240 or $720 \mathrm{mg}$ ARA daily on inflammation.

In Egyptian schoolchildren infected with S. mansoni, ARA (10 $\mathrm{mg} / \mathrm{kg}$ body weight per $\mathrm{d}$ for $5 \mathrm{~d}$ in each of 3 weeks) significantly decreased plasma IL-10 and interferon- $\gamma$ concentrations compared with study entry ${ }^{(19)}$. However, these findings are difficult to interpret because ARA was able to effectively treat the parasitic infection, and the altered plasma cytokines may simply reflect reduced pathogen burden.

In summary, the available evidence suggests little or no impact of increasing ARA intake by as much as $1.5 \mathrm{~g} / \mathrm{d}$ on immune function or on markers of inflammation, apart from a small increase in ARA-derived eicosanoid production when cells are stimulated. However, the health impact of the latter response is not known.

\section{Effect of arachidonic acid on cognitive function}

Despite ARA having an important structural and functional role in the brain ${ }^{(7)}$, there are very few RCT of cognitive function in humans where ARA is the sole intervention. Most intervention studies involving ARA have been in combination with DHA and have been undertaken during infancy.

Ishikura et $a l .{ }^{(23)}$ investigated the effects of ARA on agerelated event-related potentials in twenty-five healthy elderly Japanese men. The study was performed using a double-blind crossover design and the subjects were administered $240 \mathrm{mg} / \mathrm{d}$ 
of ARA from an ARA-enriched TAG (SUNTGA40S) in capsules or the same amount of olive oil in capsules as placebo for 1 month. Event-related potentials, which included P300 latency and amplitude, were measured before capsule administration and after 1 month of administration. In subjects administered ARA, P300 latency was significantly shorter, and P300 amplitude was significantly higher than in those administered olive oil capsules. It was concluded that supplementation of ARA may reduce age-related decline in cognitive function and learning ability. However, this is based upon a single small study and more research is needed in this important area.

\section{Effect of arachidonic acid on body composition, muscle function and physical performance}

Three double-blind RCT have reported outcomes of the effect of ARA on body composition, muscle function and physical performance $^{(20,26,29)}$. In the first study, thirty-one males from the USA were randomly assigned to receive capsules providing either $1000 \mathrm{mg}$ ARA or maize oil per d for $50 \mathrm{~d}$. No significant effects were found on body weight, fat free mass, fat mass, anabolic hormones or intramuscular markers of muscle hypertrophy ${ }^{(29)}$. However, compared with baseline, ARA supplementation increased anaerobic peak power by $8.5 \%$ at day 50 . On day 25 , the ARA supplemented group had attenuated serum IL-6 levels whereas levels of serum $\mathrm{PGE}_{2}$, a potential ergogenic factor, tended towards an increase. The authors suggested that ARA supplementation would decrease inflammation (lower IL-6), thus making intense training more tolerable. No support was found for ARA to stimulate muscle hypertrophy, which would lead to a greater strength gain and/or muscle mass due to training.

In the second study, thirty males from the USA were randomised to receive either $600 \mathrm{mg}$ ARA (from $1.5 \mathrm{~g}$ ARASYN oil) or maize oil daily during an 8-week training programme. The ARA group showed a significant increase in lean body mass (2.9\%), upper body strength ( $8.7 \%)$ and peak power $(12 \cdot 7 \%)^{(20)}$. ARA supplementation was suggested to increase post-exercise anabolic signalling rather than protein synthesis in skeletal muscle.

Markworth et al. ${ }^{(27)}$ conducted a 4-week RCT of $1500 \mathrm{mg} / \mathrm{d}$ ARA in nineteen young males involved in a resistance training programme. There was a significant reduction in fat mass $(-0.33 \mathrm{~kg}$ or $-1.7 \%)$ in the ARA group compared with the control group $(+0.49 \mathrm{~kg}$ or $+3.8 \%)$. There was no effect of ARA on lean mass and effects of ARA on leg muscle volume were small. Other measurements in these individuals were reported by Mitchell et $a l .{ }^{(26)}$ : prior ARA supplementation did not alter the acute anabolic response (i.e. muscle protein synthesis and anabolic signalling in muscle) to resistance exercise in these trained men, and the authors concluded that there is no link between ARA and short-term anabolism. However, some muscle changes were seen $48 \mathrm{~h}$ after completing the resistance exercise in men in the ARA group.

In summary, two of these studies suggest that ARA can improve peak power and may have an effect on lean body mass, while a third study suggests that ARA has an effect on late responses to resistance exercise. These effects and the underlying mechanisms require further exploration.

\section{Effect of arachidonic acid on urinary metabolites}

Ferretti et $a l .{ }^{(17)}$ reported increased urinary levels of ARA metabolites (11-dehydro-thromboxane $\mathrm{B}_{2}$ and 2,3-dinor-6-oxo-PGF ${ }_{1}$ ) following $1.7 \mathrm{~g}$ ARA per $\mathrm{d}$ for $50 \mathrm{~d}$. Kidney diuretic function, both normal and diuretic-stimulated, was not compromised in patients with liver cirrhosis (aged $>60$ years) who consumed $2 \mathrm{~g} / \mathrm{d}$ ARA for 8 weeks: urinary sodium and ARA metabolites (i.e. $\mathrm{PGE}_{2}, 6$-keto-PGF 1 , 8-epi-PGF $\mathrm{PG}_{2}$ and 11-dehydro-thromboxane $\mathrm{B}_{2}$ ) were similar to those observed in the placebo group ${ }^{(28)}$. More recently, with smaller dosages (240 or 720 mg ARA per d), for a shorter duration (4 weeks) and on a background of high DHA and EPA intake levels, ARA metabolite (11-dehydro-thromboxane $\mathrm{B}_{2}, 2,3$-dinor-6-keto-PGF $1_{\alpha}$ and 9,15dioxo-11 $\alpha$-hydroxy-13,14-dihydro-2,3,4,5-tetranor-prostan-1,20dioic acid), ) excretion in healthy Japanese elderly ( $>55$ years of age) was also found not to be affected compared with the placebo (olive oil) group ${ }^{(24)}$.

In summary, most studies report no effect of increased ARA intake on urinary excretion of ARA metabolites, and one study reports no effect of ARA on renal function in cirrhotic patients.

\section{Summary and conclusions}

The literature search identified twenty-two articles from fourteen RCT of increasing ARA intake in humans. These studies were published between 1997 and 2018. Most were conducted in adults. Studies in adults used between 40 and $2000 \mathrm{mg}$ ARA per $\mathrm{d}$, were of 1-12 weeks duration and usually used ARA as a supplement. Most studies used ARA intakes of $240-1000 \mathrm{mg} / \mathrm{d}$. Only one study investigated more than one dose of $\mathrm{ARA}^{(24)}$. Many studies were conducted in healthy young or older subjects, and several were restricted to men. One study was conducted in breast-feeding women and one in patients with liver cirrhosis. Few studies controlled the diet of the subjects under study and few studies assessed background diet. A number of studies reported the effect of ARA on FA composition of blood pools like lipids, erythrocytes and mononuclear cells, and one study reported on breast milk FA and another on skeletal muscle FA. Given the role of ARA-derived eicosanoids in regulating inflammation, immune function, platelet aggregation and blood clotting, it is not surprising that several studies investigated the effect of ARA on these outcomes. In contrast, there have been only few studies investigating effects on blood lipids, blood pressure and cognition. In most of these areas, there are too few studies to draw firm conclusions on the impact of ARA. Furthermore, the risk of bias was unclear for many of the studies, limiting the robustness of their findings.

It is clear from the existing studies that ARA supplements significantly increase the content of ARA in different blood fractions with doses as low as $80 \mathrm{mg} / \mathrm{d}$ being effective. The low dose of $40 \mathrm{mg}$ ARA per d did not affect ARA level in plasma and erythrocytes. It is likely that enrichment of ARA in different compartments and pools is dose dependent, but may become saturated at higher intakes. EPA was decreased in several studies but DHA was usually not affected by ARA supplementation, even at the highest doses tested. Often incorporation of ARA was at the expense of LA. From the available evidence, it appears that 
increasing ARA intake does not affect blood lipid concentrations or blood pressure. However, there are few such studies and the effect of ARA on blood lipids in dyslipidaemic subjects or on blood pressure in hypertensive subjects has not been investigated. Furthermore, most studies have reported no effect of increased ARA intake on platelet aggregation or coagulation parameters and no studies have seen effects on bleeding time. However, one study that used the highest intake of ARA ${ }^{(28)}$ reported enhanced platelet aggregation and this requires further investigation. The available evidence from rather detailed studies suggests little or no impact of increasing ARA intake by as much as $1.5 \mathrm{~g} / \mathrm{d}$ on immune function or on markers of inflammation, apart from a small increase in ARA-derived eicosanoid production when immune cells are stimulated. However, the effect of the latter response is not known. Several studies report no effect of increased ARA intake on urinary excretion of ARA metabolites. One study concluded that supplementation with ARA may reduce age-related decline in cognitive function and learning ability. This could be an important effect and more research should be conducted in this area. Another interesting observation is the improvement in peak power and lean body mass seen in young adults undergoing exercise training. Again these effects need further investigation along with exploration of the likely mechanisms. It is important to note that none of the studies included here was of more than 12 weeks duration, and most were shorter than this; this may be insufficient time to affect several of the outcomes assessed such as cognitive function, body composition and physical performance.

Thus, overall there seem to be few marked benefits of increasing ARA intake from the typical intake of $100-200 \mathrm{mg} / \mathrm{d}$ to as much as $1000 \mathrm{mg} / \mathrm{d}$ or perhaps even more. However, the suggested impacts on cognitive and muscle function may both be important, particularly in the ageing population, and therefore the effect of higher intakes of ARA is deserving of further study. The studies reviewed herein suggest no adverse effects of increased ARA intake up to at least 1000-1500 mg/d on blood lipids, platelet aggregation and blood clotting, immune function, inflammation or urinary excretion of ARA metabolites. However, in many areas there are insufficient studies to make firm conclusions. Based on the RCT reviewed, there are not enough data to make any recommendations for specific health effects of ARA intake.

\section{Acknowledgements}

This work was conducted by an expert group of the European branch of the International Life Sciences Institute (ILSI Europe). The expert group received funding from the ILSI Europe's Nutrient Intake Optimisation and Early Nutrition \& Long-Term Health Task Forces. Industry members of these task forces are listed on the ILSI Europe website at http://ilsi.eu/task-forces/. Experts were not paid for the time spent on this work; however, the non-industry members within the expert group received a small compensatory sum (honorarium) and travel support from the Functional Foods Task Force to attend meetings to discuss the review. The expert group carried out the work, that is, collecting/analysing data/information and writing the scientific paper separate to other activities of the task force. The research reported is the result of a scientific evaluation in line with ILSI Europe's framework to provide a precompetitive setting for public-private partnership (PPP). For further information about ILSI Europe, please email at info@ilsieurope.be or call +32 277100 14. The opinions expressed herein and the conclusions of this publication are those of the authors and do not represent the views of ILSI Europe nor those of its member companies.

ILSI Europe facilitated scientific meetings and coordinated the overall project management and administrative tasks relating to the completion of this work.

All authors conceived the research, selected papers for inclusion, carried out data extraction and assessment of papers and contributed to drafting of the manuscript. S. L. and A. S. conducted the literature search. P. C. C. had responsibility for final preparation of the manuscript. All authors read and approved the final version of the manuscript.

A. E. works for Unilever; M. F. works for Nestlé; P.-O. L. works for BASF; B. v. d. H. works for Danone; S. F. consults for DSM; P. C. C. consults for DSM, Danone/Nutricia, Cargill, BASF, FrieslandCampina and Smartfish; ILSI Europe is funded by its industry members.

\section{References}

1. Forsyth S, Gautier S \& Salem N Jr (2016) Global estimates of dietary intake of docosahexaenoic acid and arachidonic acid in developing and developed countries. Ann Nutr Metab 68 , 258-267.

2. Sioen I, van Lieshout L, Eilander A, et al. (2017) Systematic review on $n-3$ and $n-6$ polyunsaturated fatty acid intake in European countries in light of the current recommendations Focus on specific population groups. Ann Nutr Metab 70, 39-50.

3. Brenna JT, Varamini B, Jensen RG, et al. (2007) Docosahexaenoic and arachidonic acid concentrations in human breast milk worldwide. Am J Clin Nutr 85, 1457-1464.

4. Emken EA, Adlof RO \& Gulley RM (1994) Dietary linoleic acid influences desaturation and acylation of deuterium-labeled linoleic and linolenic acids in young adult males. Biochim Biophys Acta 1213, 277-288.

5. Walker C, West AL, Browning LM, et al. (2015) The pattern of fatty acids displaced by epa and dha following 12 months supplementation varies between blood cell and plasma fractions. Nutrients 7, 6281-6293.

6. Carlson SE \& Colombo J (2016) Docosahexaenoic acid and arachidonic acid nutrition in early development. Adv Pediatr 63, 453-471.

7. Hadley KB, Ryan AS, Forsyth S, et al. (2016) The essentiality of arachidonic acid in infant development. Nutrients $\mathbf{8}, 216$.

8. Witkamp RF (2018) The role of fatty acids and their endocannabinoid-like derivatives in the molecular regulation of appetite. Mol Aspects Med 64, 45-67.

9. Lewis RA, Austen KF \& Soberman RJ (1990) Leukotrienes and other products of the 5-lipoxygenase pathway. Biochemistry and relation to pathobiology in human diseases. $N$ Engl $J$ Med 323, 645-655.

10. Tilley SL, Coffman TM \& Koller BH (2001) Mixed messages: modulation of inflammation and immune responses by prostaglandins and thromboxanes. J Clin Invest 108, 15-23.

11. Dennis EA (2016) Liberating chiral lipid mediators, inflammatory enzymes, and LIPID MAPS from biological grease. $J$ Biol Chem 291, 24431-24448. 
12. Seyberth HW, Oelz O, Kennedy T, et al. (1975) Increased arachidonate in lipids after administration to man: effects on prostaglandin biosynthesis. Clin Pharmacol Therapeut 18, 521-529.

13. Nelson GJ, Schmidt PC, Bartolini G, et al. (1997) The effect of dietary arachidonic acid on platelet function, platelet fatty acid composition, and blood coagulation in humans. Lipids 32, 421-425.

14. Nelson GJ, Schmidt PC, Bartolini G, et al. (1997) The effect of dietary arachidonic acid on plasma lipoprotein distributions, apoproteins, blood lipid levels, and tissue fatty acid composition in humans. Lipids 32, 427-433.

15. Kelley DS, Taylor PC, Nelson GJ, et al. (1997) Effects of dietary arachidonic acid on human immune response. Lipids $\mathbf{3 2}$, 449-456.

16. Kelley DS, Taylor PC, Nelson GJ, et al. (1998) Arachidonic acid supplementation enhances synthesis of eicosanoids without suppressing immune functions in young healthy men. Lipids 33, 125-130.

17. Ferretti A, Nelson GJ, Schmidt PC, et al. (1997) Increased dietary arachidonic acid enhances the synthesis of vasoactive eicosanoids in humans. Lipids 32, 435-439.

18. Higgins JP, Altman DG, Sterne JA \& On behalf of the Cochrane Statistical Methods Group and the Cochrane Bias Methods Group (2011) Chapter 8: assessing risk of bias in included studies. Cochrane Handbook for Systematic Reviews of Interventions Version 5.1.0. The Cochrane Collaboration. http://handbook.cochrane.org (accessed March 2011).

19. Barakat R, Abou El-Ela NE, Sharaf S, et al. (2015) Efficacy and safety of arachidonic acid for treatment of school-age children in Schistosoma mansoni high-endemicity regions. Am J Trop Med Hyg 92, 797-804.

20. De Souza EO, Lowery RP, Wilson JM, et al. (2016) Effects of arachidonic acid supplementation on acute anabolic signaling and chronic functional performance and body composition adaptations. PLOS ONE 11, e0155153.

21. Emken EA, Adlof RO, Duval SM, et al. (1997) Influence of dietary arachidonic acid on metabolism in vivo of 8 cis, 11 cis, 14-eicosatrienoic acid in humans. Lipids 32, 441-448.

22. Hirota S, Adachi N, Gomyo T, et al. (2010) Low-dose arachidonic acid intake increases erythrocytes and plasma arachidonic acid in young women. Prostaglandins, Leukotrienes Essential Fatty Acids 83, 83-88.

23. Ishikura Y, Ikeda G, Akimoto K, et al. (2009) Arachidonic acid supplementation decreases P300 latency and increases P300 amplitude of event-related potentials in healthy elderly men. Neuropsychobiology 60, 73-79.

24. Kakutani S, Ishikura Y, Tateishi N, et al. (2011) Supplementation of arachidonic acid-enriched oil increases arachidonic acid contents in plasma phospholipids, but does not increase their metabolites and clinical parameters in Japanese healthy elderly individuals: a randomized controlled study. Lipids Health Dis 10, 241.

25. Kusumoto A, Ishikura Y, Kawashima H, et al. (2007) Effects of arachidonate-enriched triacylglycerol supplementation on serum fatty acids and platelet aggregation in healthy male subjects with a fish diet. Br J Nutr 98, 626-635.

26. Mitchell CJ, D'souza RF, Figueiredo VC, et al. (2018) Effect of dietary arachidonic acid supplementation on acute muscle adaptive responses to resistance exercise in trained men: a randomized controlled trial. J Appl Physiol 124, 1080-1091.

27. Markworth JF, Mitchell CJ, D'souza RF, et al. (2018) Arachidonic acid supplementation modulates blood and skeletal muscle lipid profile with no effect on basal inflammation in resistance exercise trained men. Prostaglandins Leukot Essent Fatty Acids 128, 74-86.

28. Pantaleo P, Marra F, Vizzutti F, et al. (2004) Effects of dietary supplementation with arachidonic acid on platelet and renal function in patients with cirrhosis. Clin Sci 106, $27-34$.

29. Roberts MD, Iosia M, Kerksick CM, et al. (2007) Effects of arachidonic acid supplementation on training adaptations in resistance-trained males. J Int Soc Sports Nutr 4, 21.

30. Schubert R, Kitz R, Beermann C, et al. (2007) Influence of low-dose polyunsaturated fatty acids supplementation on the inflammatory response of healthy adults. Nutrition $\mathbf{2 3}$, 724-730.

31. Selim S, El Sagheer O, El Amir A, et al. (2014) Efficacy and safety of arachidonic acid for treatment of Schistosoma mansoniinfected children in Menoufiya, Egypt. Am J Trop Med Hyg 91, 973-981.

32. Smit EN, Koopmann M, Boersma ER, et al. (2000) Effect of supplementation of arachidonic acid (AA) or a combination of AA plus docosahexaenoic acid on breastmilk fatty acid composition. Prostaglandins Leukot Essent Fatty Acids 62 , 335-340.

33. Thies F, Nebe-von-Caron G, Powell JR, et al. (2001) Dietary supplementation with eicosapentaenoic acid, but not with other long-chain $n$-3 or $n$-6 polyunsaturated fatty acids, decreases natural killer cell activity in healthy subjects aged $>55$ y. Am J Clin Nutr 73, 539-548.

34. Thies F, Nebe-von-Caron G, Powell JR, et al. (2001) Dietary supplementation with gamma-linolenic acid or fish oil decreases T lymphocyte proliferation in healthy older humans. J Nutr 131, 1918-1927.

35. Thies F, Miles EA, Nebe-von-Caron G, et al. (2001) Influence of dietary supplementation with long-chain $n-3$ or $n-6$ polyunsaturated fatty acids on blood inflammatory cell populations and functions and on plasma soluble adhesion molecules in healthy adults. Lipids 36, 1183-1193. 